\title{
Record of parasitic oomycetes on neotropical copepods in aquatic environments of Northwestern Patagonia (Argentina)
}

Registro de oomicetos parasíticos em copépodes neotropicais em ambientes aquáticos da Patagônia Noroeste (Argentina)

Roberto Daniel Garcia ${ }^{1,2^{*}}$ (D), Fabián Gastón Jara ${ }^{1}$ (D) and Mónica Mirta Steciow ${ }^{3}$ (D)

${ }^{1}$ INIBIOMA (UNComahue-CONICET), Quintral 1250, CP 8400, S. C. de Bariloche, Argentina

${ }^{2}$ Laboratorios de Biología, Universidad Nacional del Comahue, Quintral 1250, CP 8400, S. C. de Bariloche, Argentina

${ }^{3}$ Instituto de Botánica Spegazzini, Facultad De Ciencias Naturales y Museo - UNLP, Av. 122 and 60, CP 4198, La Plata, Argentina

*e-mail: garciarobertodaniel@gmail.com

Cite as: Garcia, R.D., Gastón Jara, F. and Mirta Steciow, M. Record of parasitic oomycetes on neotropical copepods in aquatic environments of Northwestern Patagonia (Argentina). Acta Limnologica Brasiliensia, 2020, vol. 32, e16.

Abstract: Aim: Oomycetes are one of the most widespread and destructive parasitic groups in the world. The first infection of oomycetes on copepod Parabroteas sarsi Daday 1901 was recently recorded in America. Oomycetes infection on this species makes their eggs unviable and could differentially affect the survival of females. The aim of this study was to track the incidence of oomycetes in two populations of $P$. sarsi. Methods: Two Patagonian ponds were monitored during spring-summer of 2014-2018, measuring environmental variables and the prevalence of oomycete infections on $P$. sarsi populations. Taxonomic determination of the oomycetes was performed in laboratory. Sex ratios also were recorded in each survey. Results: The presence of Aphanomyces ovidestruens Gicklhorn 1923 and Pythium flevoense Van der Plaats-Niterink 1972 was detected in females of $P$. sarsi in both ponds. We observed a decrease in the parasite prevalence over time, from $-25 \%$ (assessed on the total number of adults) to almost disappear completely. Besides, a lower proportion of females than males were observed in samples with high prevalence of parasitism. No temperature differences were found during the sampling years and the monthly temperatures between the maximum and minimum prevalences were similar. Conclusions: Our study presents a new record of oomycetes parasitizing copepods in America. Temperature can play a key role in the dynamics of parasite species, but in our study this variable not affected the incidence of the infection. However, other variables could be affect the pattern of the infection such as the presence of predators of oomycetes spores (cladocerans). The lower females proportion when the infection was higher, could support the idea of differential sex/mortality induced by the infection. Recording and identification of parasites is a critical starting point for wildlife management, which will provide an early warning to prevent the spread of harmful parasites such as oomycetes.

Keywords: zooplankton; parasitism; calanoids; wetlands; sex ratios.

Resumo: Objetivo: Os oomicetos são um dos grupos parasitários mais difundidos e destrutivos do mundo. A primeira infecção de oomicetos no copépode Parabroteas sarsi Daday 1901 foi recentemente registrada na América. A infecção por Oomycetes nesta espécie torna os seus ovos inviáveis e pode afetar diferentemente a sobrevivência das fêmeas. O objetivo deste estudo foi rastrear a incidência de oomicetos em duas populaçóes de P. sarsi. Métodos: Duas poças na patagônia foram monitoradas 
durante a primavera-verão de 2014-2018, medindo variáveis ambientais e a prevalência de infecções por oomicetos em populaçóes de $P$. sarsi. A determinação taxonômica dos oomicetos foi realizada em laboratório. As proporçóes de sexo também foram registradas em cada pesquisa. Resultados: A presença de Aphanomyces ovidestruens Gicklhorn 1923 e Pythium flevoense Van der Plaats-Niterink 1972 foi detectada em fêmeas de $P$. sarsi em ambas as poças. Observamos uma diminuição na prevalência de parasita ao longo do tempo, com uma reduçáo que foi de aproximadamente $25 \%$ (considerando o número total de adultos) até próximo de desaparecer completamente. Além disso, uma proporçáo menor de fêmeas do que de machos foi observada em amostras com alta incidência de parasitismo. Náo foram encontradas diferenças de temperatura durante os anos de amostragem e as temperaturas mensais entre as prevalências máxima e mínima foram semelhantes. Conclusão: Nosso estudo apresenta um novo registro de parasitismo por oomicetos em copépodes na América. A temperatura pode desempenhar um papel fundamental na dinâmica das espécies parasitárias, mas em nosso estudo esta variável não afetou a incidência da infecção. No entanto, outras variáveis podem afetar o padrão da infecção, como a presença de predadores de esporos de oomicetos (cladóceros). A menor proporção de fêmeas quando a infecção foi maior indicam mortalidade diferencial por sexo induzida pela infecção. $\mathrm{O}$ registo e identificação de parasitas é um ponto de partida crítico para a gestão da vida selvagem, o que proporcionará um alerta precoce para prevenir a propagaçáo de parasitas nocivos como os oomicetos.

Palavras-chave: zooplâncton; parasitismo; calanóides; zonas húmidas; proporçáo de sexos.

The oomycetes (Philum Oomycota) are one of the most destructive and widespread group of parasites in freshwater communities, affecting plankton, fishes, amphibians and reptiles (Phillips et al., 2008). Within zooplankton, oomycetes infections are concentrated in eggs sacs carried by females. Unlike cladocerans, infections on copepods are conspicuous, altering egg size and appearance through the development of hyphae (Rossetti, 2005). The oomycetes produce the complete mortality of egg, affecting the host reproduction and population growth (Redfield \& Vincent, 1979; Burns, 1985a).

Oomycetes species found on freshwater copepods belong to the genera Aphanomyces, Saprolegnia (order Saprolegniales), Pythium and Lagenidium (order Pythiales) (Valois \& Poulin, 2015). Currently, only four copepods genera have reported oomycetes infections: Boeckella in New Zealand (Burns, 1985a), Leptodiaptomus in North America (Redfield \& Vincent, 1979), Eudiaptomus in Europe (Rossetti, 2005) and Parabroteas in South America (Garcia et al., 2018).

Recently, two species of oomycetes were found together parasitizing the egg sacs of Parabroteas sarsi Daday 1901 (Calanoidea: Centropagidae) in a temporary pond located in northwestern Patagonia (Argentina). The parasites were identified as Aphanomyces ovidestruens Gicklhorn 1923 (=A. scaber) and Pythium flevoense Van der Plaats-Niterink 1972 (Garcia et al., 2018). This research was the first record of $A$. ovidestruens in
American copepods and the first record of Pythium spp. in freshwater copepods. Garcia et al. (2018) through laboratory experiments have shown that oomycetes are not lethal to females in the short-term and do not affect their susceptibility to insect predation. However, the proportion of females decreased after the spread of the infection, when the daily water temperature increased above $20{ }^{\circ} \mathrm{C}$. Temperature play a key role in the dynamics of parasite species and can alter host susceptibility (Mitchell et al., 2005). For example, increasing temperature favoring Aphanomyces sp. growth and zoospore production (Valois, 2015). The effectiveness of the infection also depends on the host condition. In P. sarsi, the oomycete infection produces an additional cost associate with the generation of a new egg sac, and could reduce the life expectancy of females in the long-term, as has been shown in Burns (1985b) for others copepod species. On the other hand, temperature also affects physiology parameters such as metabolism level and oxygen consumption that, in turn, affect copepod's ability to resist environmental changes (Huntley \& Lopez, 1992). High temperatures can accelerate metabolism and oxygen consumption, leading to excessive use of protein and a low survival rate (Li et al., 2009; Garcia \& Diéguez, 2014). It is possible that a combination of these factors imposes severe restraints on $P$. sarsi females from spring onwards, differentially affecting their survival (Garcia et al., 2018). However, little is known regarding this aspect and further investigation is required on the subject. Decline of the $P$. sarsi populations could have a pronounced effect on the aquatic food webs, due to this copepod representing a fundamental trophic link between 
primary producers and vertebrates in Patagonia (Reissig et al., 2004; Garcia et al., 2013a). Therefore, the aim of this study was to track the incidence of oomycetes parasites in two populations of $P$. sarsi.

Two ponds were sampled in six opportunities in total during November and December of 2014-2018. One is an urban pond located inside the city of S. C. de Bariloche (Fantasma pond), while the other pond is located at piedmont of Cerro Catedral (Cerro Catedral pond) and surrounded by well-preserved forest of Nothofagus pumillo (Table 1). These wetlands are wet meadows mainly dominated by herbaceous plants belonging to the Cyperaceae, Juncaceae and Poaceae families (Cuassolo et al., 2016). Both ponds are temporary flooded by rainfall and snowmelt (April-May) and dry frequently in early summer (December-January). Sometimes, in very wet years, they turn in semi-permanent environments (alternating years of seasonally dry versus inundated). Electrical conductivity and water temperature were measured with a YSI85 multiprobe, and $\mathrm{pH}$ was measured with a Hanna HI98150 probe. The maximum depth of the ponds was also recorded. Meteorological data was obtained from an automated weather monitor (Davis Vantage Pro) located at the EMMA Met-Station (INIBIOMA, CONICET-UNComahue; $41^{\circ} 7^{\prime} 43.33^{\prime \prime} S$; $71^{\circ} 25^{\prime} 12.03^{\prime \prime} \mathrm{W} ; 800 \mathrm{~m}$ a.s.l). Copepods were collected with a hand net $(1 \mathrm{~mm}$ mesh) from several sampling points in open waters. The sex ratio and prevalence of parasitism were determined by examining random samples of 50 to 200 P. sarsi adults on each survey, depending on the abundance of copepods. The Fantasma pond population was sampled four times, while Cerro Catedral pond population was sampled only twice. Oomycetes infection in females is easily recognized by the change in the colour of eggs (white and/or blue instead of dark brown) (Garcia et al., 2018). Oomycete samples were obtained from infected P. sarsi females in laboratory. Water cultures of oomycetes were placed in sterilized Petri dishes containing several halves of hemp Cannabis sativa seeds used as bait and were incubated at room temperature $\left(15\right.$ to $\left.20{ }^{\circ} \mathrm{C}\right)$. After 2 weeks, the oomycetes species were confirmed using water cultures from their monosporic isolates in cornmeal-agar medium (CMA) (Dick, 2001; Johnson et al., 2002).

The studied ponds had similar maximum sizes and depths. Conductivity and $\mathrm{pH}$ were higher in the Fantasma compared to Cerro Catedral pond, while water temperature was similar in both studied sites (Table 1). Both ponds presented females of $P$. sarsi with eggs parasitized with the oomycetes A. ovidestruens and P. flevoense.

The oomycetes prevalence recorded in Fantasma pond during 2009 was $19 \%$ of the total population of P. sarsi (53\% of females were infected) (Garcia et al., 2018). In our study, the same environment showed a prevalence of $15-26 \%$ ( $40-66 \%$ of females were infected) in 2014, only a $0.5 \%$ in 2017 (1.0\% of

Table 1. Geographical location, morphometric and limnological parameters of the studied ponds (Northwestern Patagonia, Argentina). References: $\mathrm{Z}_{\max }$ : Maximum depth; Temp: Water temperature; EC: Electrical conductivity; NA: Not available. Data are shown as mean (standard deviation).

\begin{tabular}{|c|c|c|c|c|c|c|c|c|}
\hline Pond & $\begin{array}{c}\text { Geographical } \\
\text { location; } \\
\text { Altitude (m a.s.l) }\end{array}$ & $\begin{array}{l}Z_{\max } \\
(\mathrm{m})\end{array}$ & $\begin{array}{l}\text { Area } \\
\left(\mathrm{hm}^{2}\right)\end{array}$ & $\begin{array}{l}\text { Temp } \\
\left({ }^{\circ} \mathrm{C}\right)\end{array}$ & $\begin{array}{c}E C \\
\left(\mu S \mathrm{~cm}^{-1}\right)\end{array}$ & $\mathrm{pH}$ & $\begin{array}{c}\text { Degree of } \\
\text { urbanization }\end{array}$ & $\begin{array}{l}\text { Trophic } \\
\text { state }\end{array}$ \\
\hline Fantasma & $\begin{array}{c}41^{\circ} 05^{\prime} 33^{\prime \prime} \mathrm{S} \\
71^{\circ} 27^{\prime} 00^{\prime \prime} \mathrm{W} \\
794\end{array}$ & $1.0(0.3)$ & 1.2 & $16.4(3.4)$ & $91.9(6.0)$ & $7.6(0.2)$ & $\begin{array}{l}\text { Very } \\
\text { high }\end{array}$ & Eutrophic \\
\hline Cerro Catedral & $\begin{array}{c}41^{\circ} 12^{\prime} 07^{\prime \prime S} \\
71^{\circ} 25^{\prime} 40^{\prime \prime} \mathrm{W} \\
978\end{array}$ & $1.2(0.1)$ & 1.0 & $20.9(0.2)$ & $62.6(16.2)$ & $6.8(0.3)$ & Null & NA \\
\hline
\end{tabular}

Table 2. Sex ratios and parasite prevalence in Parabroteas sarsi populations. References: Temp: Air temperature. Data are shown as mean (standard deviation).

\begin{tabular}{|c|c|c|c|c|c|c|c|c|}
\hline Pond & Dates & $\begin{array}{c}\text { Males } \\
(\%)\end{array}$ & $\begin{array}{c}\text { Healthy } \\
\text { females } \\
(\%)\end{array}$ & $\begin{array}{c}\text { Infected } \\
\text { females (\%) }\end{array}$ & $\phi: \hat{0}$ & $\begin{array}{c}\text { Monthly } \\
\text { Temp } \\
\left({ }^{\circ} \mathrm{C}\right)\end{array}$ & $\begin{array}{c}\text { Annual } \\
\text { Temp }\left({ }^{\circ} \mathrm{C}\right)\end{array}$ & $\begin{array}{c}\text { Rain } \\
\left(\mathrm{mm}^{2} \text { year }^{-1}\right)\end{array}$ \\
\hline \multirow[t]{4}{*}{ Fantasma } & Nov-2014 & $61.4(7.6)$ & $12.5(5.3)$ & $26.1(10.7)$ & $1: 1.6$ & $10.5(2.5)$ & $8.7(7.7)$ & 1597 \\
\hline & Dec-2014 & $65.7(24.8)$ & $19.4(7.6)$ & $14.9(9.7)$ & $1: 1.9$ & $13.2(2.6)$ & & \\
\hline & Dec-2017 & $17.5(7.9)$ & $82.0(14.1)$ & $0.5(1.1)$ & $1: 0.2$ & $14.2(3.0)$ & $9.5(6.1)$ & 1340 \\
\hline & Nov-2018 & $31.3(14.3)$ & $68.8(16.5)$ & $0.0(0.0)$ & $1: 0.4$ & $10.6(2.6)$ & $7.8(6.6)$ & 1070 \\
\hline Cerro & Dec-2017 & $56.6(4.5)$ & $19.0(3.5)$ & $24.4(3.1)$ & $1: 1.3$ & $14.2(3.0)$ & $9.5(6.1)$ & 1340 \\
\hline Catedral & Dec-2018 & $35.5(4.6)$ & $45.2(0.1)$ & $3.0(0.1)$ & $1: 0.6$ & $14.1(2.9)$ & $7.8(6.6)$ & 1070 \\
\hline
\end{tabular}


the females), while there were no signs of infection in 2018 (Table 2). The parasite prevalence in Cerro Catedral pond during 2017 was similar to those recorded in Fantasma pond during 2010 and 2014, with a prevalence of $24 \%$ in the population (56\% of the females), while a very low prevalence (3\%) was recorded in 2018 (Table 2). Ponds in Patagonia generally experience interannual fluctuation in the rainfall patterns and local temperatures (Perotti et al., 2005). These parasites have a positive relationship between temperature and its prevalence (Valois, 2015; Garcia et al. 2018), therefore the reduction of infection could be associated with the variability of temperature. However, we did not find differences in annual temperature between the years 2014, 2017 and 2018 (Table 2) (One-Way ANOVA, F = 0.186, n = $12, \mathrm{df}=2, \mathrm{p}=0.831)$ and the monthly temperatures between maximum and minimum prevalence of parasites were similar (Table 2) (Cerro Catedral: t-test, $\mathrm{t}=0.225, \mathrm{n}=31, \mathrm{p}=0.823$; Fantasma: $\mathrm{t}$-test, $\mathrm{t}=0.245, \mathrm{n}=30, \mathrm{p}=0.807)$. Other variables could be affect the pattern of the infection such as the presence of predators of oomycetes spores (cladocerans) (Valois \& Burns, 2016; Garcia et al. 2018). Indeed, both ponds have high densities of cladoceran (Daphnia sp. and Ceriodaphnia sp) during the studied period (authors' pers. obs.). However, further investigations are necessary to check this assumption.

Sampling dates with presence of parasites showed an asymmetric sex proportion with males dominating the structure of the populations. In contrast, dates without infection detection, we observed dominance of females (Table 2). This result could support the idea that oomycetes generate differential mortality on females (Garcia et al., 2018). However, the reasons for the reduction of males in periods without infection are unknown, considering that in Centropagidae family the female:male ratios tends to be equal (Kiørboe, 2006).

Fantasma is a eutrophic pond that receives inputs of allochthonous organic matter from the surrounding urbanization and non-native trees, in contrast with Cerro Catedral pond that is located in a non-urbanized area surrounded by native forest, where human impact is negligible. In this sense, the spread of oomycetes and their effects on copepods appear not be associated to anthropogenic activities. The finding of oomycetes in Cerro Catedral pond corresponds to a new record of A. ovidestruens and $P$. flevoense parasitizing copepods, future investigations must focus in the monitoring different populations.

P. sarsi is considered the largest freshwater copepod reaching $5 \mathrm{~mm}$ in body size. Its body size (Garcia et al., 2013b) has facilitated the detection of parasite infection. It is probable that other smaller species of Patagonian copepods are being affected by oomycetes, but their records are ignored due to the small size of their egg sacs. Parasite identification and monitoring is a critical starting point for wildlife management (Tompkins et al., 2015). For this reason, it is necessary to continue the studies on parasitic biodiversity on aquatic environments (Steciow, 2005). The understanding of infectious processes and their causal mechanisms will be indispensable to better predict the impact and spread of harmful parasites, such as oomycetes.

\section{Acknowledgements}

We are grateful to the $S$. C. de Bariloche Town Council (authorizations n ${ }^{\circ} 52-A P-16$ and $n^{\circ} 1532$ ) and the Administration of the Nahuel Huapi National Park for granting permission to sample the pond within their jurisdictions. We thank PE García and EC Soto Cárdenas for their assistance in field work. We thank to anonymous referee for his/her valuable comments on the manuscript. RD Garcia holds a CONICET fellowship. FG Jara and MM Steciow are CONICET researchers.

\section{References}

BURNS, C.W. Fungal parasitism in a copepod population: the effects of Aphanomyces on the population dynamics of Boeckella dilatata Sars. Journal of Plankton Research, 1985a, 7(2), 201-205. http://dx.doi.org/10.1093/plankt/7.2.201.

BURNS, C.W. Fungal parasitism in a freshwater copepod: components of the interaction between Aphanomyces and Boeckella. Journal of Invertebrate Pathology, 1985b, 46(1), 5-10. http://dx.doi. org/10.1016/0022-2011(85)90123-5.

CUASSOLO, F., NAVARRO, M.B., BALSEIRO, E. and MODENUTTI, B. Effect of light on particulate and dissolved organic matter production of native and exotic macrophyte species in Patagonia. Hydrobiologia, 2016, 766(1), 29-42. http://dx.doi. org/10.1007/s10750-015-2434-7.

DICK, M.W. Straminipilous fungi. Systematics of the Peronosporomycetes including account of the marine straminipilous protists, the plasmodiophorids and similar organisms. Dordrecht: Kluwer Academic Publishers, 2001.

GARCIA, P.E. and DIÉGUEZ, M.C. Vulnerability of Patagonian planktonic copepods to fluctuations in 
temperature and UVR. Crustaceana, 2014, 87(3), 291-304. http://dx.doi.org/10.1163/1568540300003288.

GARCIA, R.D., GARCIA, P.E. and REISSIG, M. Sexual size dimorphism in calanoid copepods (Centropagidae) from Patagonia (Argentina). New Zealand Journal of Marine and Freshwater Research, 2013a, 47(4), 504-514. http://dx.doi.org/10.1080/ 00288330.2013 .802699$.

GARCIA, R.D., REISSIG, M. and DIÉGUEZ, M.C. Parabroteas: El pequeño gigante de la Patagonia. Difundiendo Saberes Desde la Patagonia, 2013b, 10(15), 2-9.

GARCIA, R.D., JARA, F.G., STECIOW, M.M. and REISSIG, M. Oomycete parasites in freshwater copepods of Patagonia: effects on survival and recruitment. Diseases of Aquatic Organisms, 2018, 129(2), 123-134. http://dx.doi.org/10.3354/dao03240. PMid:29972373.

HUNTLEY, M.E. and LOPEZ, M.D.G. Temperaturedependent production of marine copepods: a global synthesis. American Naturalist, 1992, 140(2), 201-242. http://dx.doi.org/10.1086/285410. PMid:19426057.

JOHNSON, T.W., SEYMOUR, R.L. and PADGETT, D.E. Biology and systematics of the Saprolegniaceae. Wilmington: University of North Carolina at Wilmington, 2002 [viewed 26 may 2020]. Available from: http://dl.uncw.edu/digilib/Biology/Fungi/ Taxonomy $\% 20$ and $\% 20$ Systematics/Padgett $\% 20$ Book/Preface.pdf

KIØRBOE, T. Sex, sex-ratios, and the dynamics of pelagic copepod populations. Oecologia, 2006, 148(1), 40-50. http://dx.doi.org/10.1007/s00442005-0346-3. PMid:16425044.

LI, C., LUO, X., HUANG, X. and GU, B. Influences of temperature on development and survival, reproduction and growth of a calanoid copepod (Pseudodiaptomus dubia). TheScientific WorldJournal, 2009, 9, 866-879. http://dx.doi.org/10.1100/ tsw.2009.96. PMid:19734960.

MITCHELL, S.E., ROGERS, E.S., LITTLE, T.J. and READ, A.F. Host-parasite and genotype-byenvironment interactions: temperature modifies potential for selection by a sterilizing pathogen. Evolution; International Journal of Organic Evolution, 2005, 59(1), 70-80. http://dx.doi.org/10.1111/j.0014-3820.2005. tb00895.x. PMid:15792228.

PEROTTI, M.G., DiÉGUEZ, M.C. and JARA, F.G. Estado del conocimiento de humedales del norte patagónico (Argentina): aspectos relevantes e importancia para la conservación de la biodiversidad regional. Revista Chilena de Historia Natural, 2005, 78(4), 723-737. http://dx.doi.org/10.4067/S0716078X2005000400011.

PHILLIPS, A.J., ANDERSON, V.L., ROBERTSON, E.J., SECOMBES, C.J. and VAN WEST, P. New insights into animal pathogenic oomycetes. Trends in Microbiology, 2008, 16(1), 13-19. http://dx.doi. org/10.1016/j.tim.2007.10.013. PMid:18096392.

REISSIG, M., MODENUTTI, B., BALSEIRO, E. and QUEIMALINOS, C. The role of the predaceous copepod Parabroteas sarsi in the pelagic food web of a large deep Andean lake. Hydrobiologia, 2004, 524(1), 67-77. http://dx.doi.org/10.1023/ B:HYDR.0000036120.33105.05.

REDFIELD, G. and VINCENT, W. Stages of infection and ecological effects of a fungal epidemic on the eggs of a limnetic copepod. Freshwater Biology, 1979, 9(6), 503-510. http://dx.doi. org/10.1111/j.1365-2427.1979.tb01534.x.

ROSSETTI, G. Fungal parasitism in freshwater calanoid population: consequences and possible mechanisms involved in the infection process. Hydrobiologia, 2005, 548(1), 167-176. http://dx.doi.org/10.1007/ s10750-005-4168-4.

STECIOW, M.M. Estudio cuantitativo de los oomycetes del río Santiago y afluentes (Buenos Aires, Argentina). Natura Neotropicalis, 2005, 2(27), 119-126. http:// dx.doi.org/10.14409/natura.v2i27.3686.

TOMPKINS, D.M., CARVER, S., JONES, M.E., KRKOŠEK, M. and SKERRATT, L.F. Emerging infectious diseases of wildlife: a critical perspective. Trends in Parasitology, 2015, 31(4), 149-159. http://dx.doi.org/10.1016/j.pt.2015.01.007. PMid:25709109.

VALOIS, A.E. The distribution, phylogeny, and ecology of brood parasitism in calanoid copepods [PhD dissertation]. 2015, Dunedin: University of Otago.

VALOIS, A.E. and BURNS, C.W. Parasites as prey: Daphnia reduce transmission success of an oomycete brood parasite in the calanoid copepod Boeckella. Journal of Plankton Research, 2016, 38(5), 12811288. http://dx.doi.org/10.1093/plankt/fbw055.

VALOIS, A.E. and POULIN, R. Global drivers of parasitism in freshwater plankton communities. Limnology and Oceanography, 2015, 60(5), 17071718. http://dx.doi.org/10.1002/lno.10127.

Received: 28 January 2019 Accepted: 26 May 2020

Associate Editors: André Megali Amado. 